\title{
Pancytopenia and folate deficiency in alcoholics
}

\author{
Clive F.M. Weston and Michael J. Hall
}

Department of Medicine, Bristol Royal Infirmary, Bristol BS2 8HW, UK.

\begin{abstract}
Summary: Three alcoholic patients are reported who presented with pancytopenia and macrocytosis due to acute folate deficiency. While folate deficiency is a common finding in alcohol abusers due to abnormalities in diet, intestinal absorption, internal metabolism and excretion, this life-threatening complication has not been well documented.
\end{abstract}

\section{Introduction}

A low serum or red cell folate is a frequent finding in chronic alcoholics who may or may not have megaloblastic anaemia. Although pancytopenia due to folate deficiency has been reported as a complication of intravenous nutrition and haemodialysis it has not been well documented in alcoholics with liver disease. We report the cases of three patients who were admitted within an 18 month period with severe pancytopenia and low or undetectable red cell folate levels. Two of the patients were known alcoholics and the other, who initially denied alcohol ingestion, was later readmitted with alcoholic hepatitis.

\section{Case reports}

\section{Patient 1}

A 37 year old woman was admitted in November 1983 with a three month history of malaise, anorexia and weight loss. She had become increasingly dyspnoeic and had experienced fever, urinary frequency and haematuria. Her only drug therapy was amitryptyline and she claimed only occasional alcohol intake.

On examination she was ill, anaemic with multiple bruises, ulcerated bleeding gums, and oral candidiasis. Other signs were hepatomegaly, generalized muscle wasting and a retinal haemorrhage in the right eye.

Blood analysis revealed pancytopenia with a haemoglobin of $4.6 \mathrm{~g} / \mathrm{dl}$, white cell count of $1.3 \times 10^{9} / 1$, and platelets $55 \times 10^{9} / 1$. Mean corpuscular volume (MCV) was $115 \mathrm{fl}$ and nucleated red cells and hypersegmented neutrophils were seen. Clotting times were abnormal with a prothrombin time of 18 seconds and activated partial thromboplastin time of 50 seconds. The concentration of fibrin degradation products was

Correspondence: C.F.M. Weston, M.B., M.R.C.P.

Accepted: 10 September 1986 between 40 and $80 \mathrm{mg} / 1$. Plasma urea was $1.3 \mathrm{mmol} / \mathrm{l}$, sodium $138 \mathrm{mmol} / 1$, potassium $2.8 \mathrm{mmol} / 1$ and levels of serum liver enzymes, calcium and phosphate were normal. Serum ferritin was greater than 500 (normal range 15-99) $\mathrm{ng} / \mathrm{ml}$, vitamin $B_{12} 377$ (normal range $150-800) \mathrm{ng} / \mathrm{l}$ but the red cell folate was unrecordable. The bone marrow was megalobastic.

The patient was resuscitated with broad-spectrum antibiotics, transfusions of blood, platelets and fresh frozen plasma, potassium supplements, vitamin $\mathbf{B}_{12}$ injections and oral folic acid, and by the seventh day of her stay her haemoglobin was $9.4 \mathrm{~g} / \mathrm{dl}$, reticulocyte count $5 \%$, white cell count $10.7 \times 10^{9} / 1$ and platelets $268 \times 10^{9} / 1$. A dietary assessment and further investigations were not possible as the patient became uncooperative and discharged herself.

She failed to attend out-patient follow-up and was readmitted one year later with a recurrence of previous symptoms. She now admitted to an alcohol intake of 2 bottles of sherry per day over a period of 15 years. There were signs of liver failure with encephalopathy, jaundice and ascites. She was again anaemic with haemoglobin of $7.0 \mathrm{~g} / \mathrm{dl}$ and MCV $117 \mathrm{fl}$, but there was neither pancytopaenia nor vitamin $B_{12}$ or folate deficiency. Liver function was grossly abnormal with elevated transaminases, hypoalbuminaemia and prolonged clotting time. There was no evidence of viral hepatitis and auto-antibody screening was negative. A diagnosis of acute alcoholic hepatitis was made. The liver failure improved slowly and she abstained from further alcohol.

Currently the patient remains well, albeit with signs of chronic liver disease and troublesome pains in her legs due to peripheral neuropathy.

\section{Patient 2}

A 26 year old woman was noted to have a macrocytosis which was demonstrated to be due to 
folate deficiency in 1975. In the presence of a normal jejunal biopsy and the absence of a history of alcohol intake this was felt to be due to continuous oral contraceptive therapy.

Four years later she was referred to a psychiatrist requesting help with a long-term problem of alcohol abuse. At the age of 34 years she was admitted with alcoholic hepatitis (biopsy-proven) and marked peripheral neuropathy. Nerve conduction studies showed definite peripheral sensory dysfunction. The red cell folate was low at $76 \mu \mathrm{g} / \mathrm{l}$ (normal range $120-650$ ), the haemoglobin was $11.1 \mathrm{~g} / \mathrm{dl}$ and MCV $111 \mathrm{fl}$.

She continued to drink heavily and 2 years later, in 1985, was admitted with a three week history of fatigue, dizziness, fever, menorrhagia and epistaxis. On examination she was anaemic with bruising, haematuria and rectal bleeding. There was tender hepatomegaly but no ascites. She was pyrexial with a tachycardia and hypotension with a postural drop in blood pressure. There was evidence of a proximal myopathy and peripheral neuropathy.

Blood analysis revealed a haemoglobin of $4.0 \mathrm{~g} / \mathrm{dl}$, white cell count of $3.7 \times 10^{9} / 1$, platelets $15 \times 10^{9} / 1$, MCV $152 \mathrm{fl}$, with many nucleated red cells and hypersegmented neutrophils. Plasma potassium was $3.9 \mathrm{mmol} / 1$ (but fell to $2.2 \mathrm{mmol} / 1$ on folic acid therapy) albumin was $25 \mathrm{~g} / \mathrm{l}$, bilirubin $25 \mu \mathrm{mol} / \mathrm{l}$, aspartate aminotransferase (AST) $71 \mathrm{IU} / 1$ fasting triglycerides $3.38 \mathrm{mmol} / 1$ and cholesterol $3.34 \mathrm{mmol} / \mathrm{l}$. Serum ferritin was $1560 \mathrm{ng} / \mathrm{ml}$, vitamin $B_{12} 190 \mathrm{ng} / 1$ and red cell folate was undetectable.

Treatment was with antibiotics, platelet and blood transfusions, oral folic acid and vitamin $B_{12}$ injections. A reticulocyte count of $28 \%$ was achieved 10 days after admission, with a white cell count of $16 \times 10^{9} / 1$ and platelets of $246 \times 10^{9} / 1$ (see Figure 1).

Jejunal biopsy, small bowel barium follow-through and gastroscopy were normal and liver biopsy confirmed changes characteristic of alcohol abuse.

\section{Patient 3}

In 1981 a 54 year old Hungarian man developed a left ileo-femoral vein thrombosis and was coincidentally found to have a macrocytosis and red cell folate of $91 \mu \mathrm{g} / \mathrm{l}$. He denied alcohol intake and a jejunal biopsy was normal. After 3 months treatment with folic acid the MCV had fallen from 112 to $102 \mathrm{fl}$ and haemoglobin had risen from 16.3 to $20.2 \mathrm{~g} / \mathrm{dl}$ with a packed cell volume of 0.61 . There were abnormal liver function tests and although he continued to deny alcohol abuse a random serum ethanol level was $173 \mathrm{mg} / 100 \mathrm{ml}$. A bone marrow biopsy demonstrated increased stainable iron and many abnormal sideroblasts. It was felt he had 'stress' polycythaemia and required venesections.

Two years later he was admitted with a lung abscess
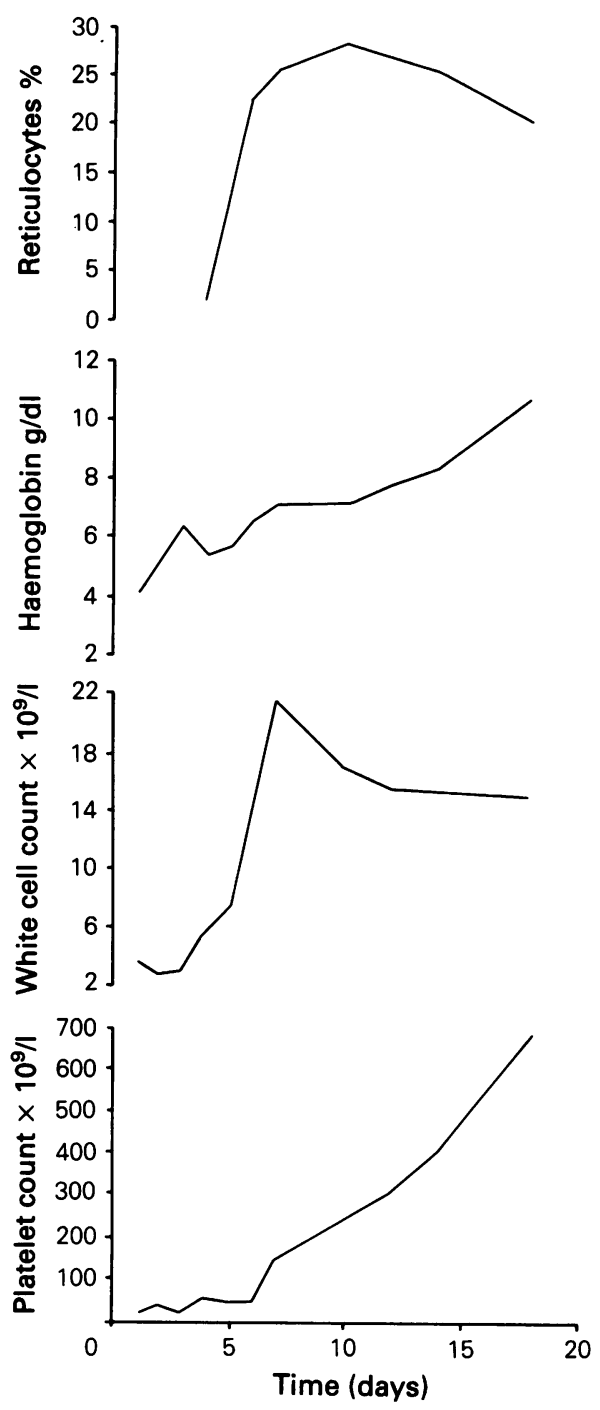

Figure 1 Progress of patient number 2 (see text).

and soon developed a confusional state. When he응 recovered he was noted to have a tremor, a peripheral neuropathy and poor short-term memory.

He was admitted in 1985 with a four week history of malaise, weakness, anorexia, weight loss and diarr- $\odot$ hoea. On examination he was pale, thin and apyrexial 0 with a resting tachycardia and mild ankle oedema. There was tender hepatomegaly and a peripheral neuropathy with absent knee and ankle jerks. Occult ${ }_{0}^{2}$ blood was detected in the faeces and blood analysis $\frac{\sim}{\varnothing}$ revealed haemoglobin $6.7 \mathrm{~g} / \mathrm{dl}$, white cell count $\stackrel{\infty}{+}$ $1.8 \times 10^{9} / 1$, platelets $24 \times 10^{9} / 1$ and, MCV $134 \mathrm{fl}$. Serum potassium was $2.5 \mathrm{mmol} / 1$, urea $3.2 \mathrm{mmol} / 1$, 
albumin $27 \mathrm{~g} / \mathrm{l}$, AST $44 \mathrm{IU} / 1$, fasting triglycerides $1.79 \mathrm{mmol} / \mathrm{l}$ and cholesterol $3.03 \mathrm{mmol} / \mathrm{l}$. Serum ferritin was $195 \mathrm{ng} / \mathrm{ml}$, vitamin $B_{12} 371 \mathrm{ng} / \mathrm{l}$ and red cell folate was low at $77 \mu \mathrm{g} / \mathrm{l}$. An ultrasound of the abdomen showed an echogenic probably cirrhotic liver, moderate ascites and gallstones within a shrunken, thick-walled gall bladder, and normal sized spleen.

Treatment was with intramuscular vitamin $\mathbf{B}_{12}$ and oral folic acid and a reticulocyte count of $18.0 \%$ was achieved by day 7 , and $22 \%$ on day 10 , by which time his white cell count had returned to $4.9 \times 10^{9} / 1$ and platelets to $197 \times 10^{9} / 1$.

\section{Discussion}

Such severe pancytopenia as a result of folate deficiency in chronic alcoholics with liver disease has not previously been reported, and yet our experience suggests that it is not a rare occurrence. Some degree of pancytopenia may occur in patients with portal hypertension and hypersplenism but none of our patients had palpable splenomegaly and all responded to folic acid therapy with return of red cell, white cell and platelet counts towards normal.

Folic acid deficiency is the most frequently seen nutritional defect in alcoholics and is related to a number of factors. Alcoholics often ingest folatedeficient diets. A study comparing 'skid-row' alcohol abusers with well-nourished middle-class American alcoholics revealed folate deficiency in the former but not in the latter except in the presence of high blood ethanol levels. ${ }^{1}$ While a more recent British survey of 84 alcoholics admitted to a general medical ward showed red cell folate deficiency in one third, this occurred significantly more frequently in those patients on an 'inadequate' diet. $^{2}$ Dietary folate deficiency appears to be a major contributory factor in the intestinal malabsorption present in these patients. Individuals who chronically ingest alcohol show a more pronounced reduction in sodium and water absorption, also in absorption of $d$-xylose, glucose and folic acid itself, if maintained on a folate-free diet than those alcoholics on an adequate diet. ${ }^{3,4}$ There are also morphological changes in intestinal mucosal cells due to alcohol and folate-deficiency but the significance is uncertain. Alcohol itself does not cause folate malabsorption in normal subjects in the absence of a low serum folate.

Internal folic acid metabolism is also affected by ethanol. The gradual fall in serum folate seen in normal subjects on folate-deficient diets is greatly accelerated on ingestion of alcohol and is associated with megaloblastic marrow changes within 10 days. These reverse on stopping the alcohol and it has been suggested that there is a reversible sequestration of folate within hepatocytes and acute interruption of the enterohepatic circulation of methyltetrahydrofolate. ${ }^{5}$ However, the physiological significance of this disturbance of intestinal folic acid metabolism is probably very small, ${ }^{6}$ certainly when compared with the documented increase in urinary folate loss following alcohol consumption.?

Reversible sideroblastic anaemia with haemoglobins ranging from 6.0 to $10.0 \mathrm{~g} / \mathrm{dl}$ was detected by Hines in 13 severe alcoholics, all of whom had megaloblastic marrows and low levels of potassium, magnesium and folate. ${ }^{8}$ In a study of 65 acutely ill alcoholics in the United States, 28 had megaloblastic haemopoiesis due to folate deficiency. Six patients had thrombocytopenia and two of these had white cell counts of less than $5 \times 10^{9} / 1$ that returned to normal on folic acid treatment. In general these 28 patients drank more and had a poorer diet. Seven of the 9 reported deaths occurred in this group. ${ }^{9}$

Acute folate deficiency leading to megaloblastic haemopoiesis, pancytopenia and sometimes spontaneous bleeding has been reported in patients receiving peritoneal dialysis, ${ }^{10}$ those on intensive care, ${ }^{11,12}$ and those receiving intravenous nutrition ${ }^{13}$ and folic acid supplements are recommended. In 3 patients reported by Wardrop ${ }^{13}$ who received intravenous aminoacid/ethanol nutrition (equivalent to half a bottle of spirits per day) pancytopenia developed between 3 and 36 days in the presence of normal red blood cell folate but low serum folate.

Our experience suggests that chronic alcoholics with liver disease, who are frequently folate deficient, are at risk of life-threatening pancytopenia. Current knowledge suggests that the risk is highest when a dietary folate deficiency is combined with a severe disturbance of internal folic acid metabolism and acutely increased urinary folate loss as might be produced by binge drinking.

\section{Acknowledgements}

We would like to thank Professor Read for allowing us to report his patients and we would also like to thank Victoria Blake for secretarial assistance.

\section{References}

1. Eichner, E.R., Buchanan, B., Smith, J.W. \& Hillman, R.S. Variation in the hematologic and medical

status of alcoholics. Am J Med Sci 1971, 263: 35-42.

2. Wu, A., Chanarin, I., Slavin, G. \& Levi A.J. Folate de- 
ficiency in the alcoholic - its relationship to clinical and haematological abnormalities, liver disease and folate status. Br J Haematol 1975, 29: 469-478.

3. Mekhjian, H.S. \& May, E.S. Acute and chronic effects of ethanol on fluid transport in the human small intestine. Gastroenterology 1977, 72: 1280-1286.

4. Halstead, C.H., Robles, E.A. \& Mezey, E. Intestinal malabsorption in folate-deficient alcoholics. Gastroenterology 1973, 64: 526-532.

5. Hillman, R.S. \& Steinberg, S.E. The effects of alcohol on folate metabolism. Ann Rev Med 1982, 33: 345-354.

6. Weir, D.G., McGing, P.G. \& Scott, J.M. Folate metabolism, the enterohepatic circulation and alcohol. Biochem Pharmacol 1985, 34: 1-7.

7. McMartin, K.E. \& Collins, T.D. Role of ethanol metabolism in the alcohol-induced increase in urinary folate excretion in rats. Biochem Pharmacol 1983, 32: 2549-2555.
8. Hines, J.D. Reversible megaloblastic and sideroblastic marrow abnormalities in alcoholic patients. $B r J_{\varrho}^{\overparen{尺}}$ Haematol 1969, 16: 87-101.

9. Eichner, E.R. \& Hillman, R.S. The evolution of anaemia in alcoholic patients. Am J Med 1971, 50: 218-32.

10. Watson, A.J.S., Lawlor, E. \& Keogh, J.A.B. Acute folate deficiency during peritoneal dialysis. $\mathrm{Br} \mathrm{Med} J 1980,281$ : 1602.

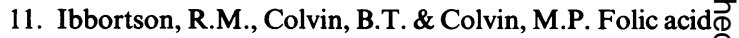

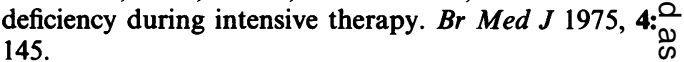

12. Beard, M.E.J., Hatipov, C.S. \& Hamer, J.W. Acutemarrow folate deficiency during intensive care. $\mathrm{Br} \mathrm{Med} \mathrm{J}_{-}^{\circ}$ 1978. 1: 624-625.

13. Wardrop, C.A.J., Heatly, R.V., Tennant, G.B. \& Hughes L.E. Acute folate deficiency in surgical patients on aminoacid/ethanol IV nutrition. Lancet 1975, ii: 3 $640-642$. 